\title{
PENGARUH CAMPURAN ABU SABUT KELAPA DENGAN TANAH LEMPUNG TERHADAP NILAI CBR TERENDAM (SOAKED) DAN CBR TIDAK TERENDAM (UNSOAKED)
}

\author{
Adzuha Desmi $^{1)}$, Utari Sniwati ${ }^{2}$ \\ Jurusan Teknik Sipil Universitas Malikussaleh \\ email: adz.desmi@gmail.com ${ }^{1)}$,utarisniwati@yahoo.co.id $^{2)}$
}

\begin{abstract}
Abstrak
Lempung adalah terdiri dari butiran-butiran sangat kecil dan menunjukkan sifat plastisitas dan kohesif. Pada penelitian ini digunakan abu sabut kelapa untuk perbaikan tanah lempung didesa Cot Girek Kandang yang berdaya dukung rendah. Tujuan penelitian ini adalah untuk mengetahui nilai CBR terendam (soaked) dan CBR tak terendam (unsoaked) dengan variasi campuran 5\%, $10 \%$, dan $15 \%$ abu sabut kelapa. Tanah di desa cot girek kandang termasuk tanah lempung berpasir. Berat volume $1,60 \mathrm{gram} / \mathrm{cm}^{3}$ dan kadar air optimum $28 \%$. Pada pengujian CBR terendam tanah asli didapat nilai 5,0\% sedangkan setelah dicampur 5\% abu sabut kelapa didapat nilai $16,67 \%$, pada $10 \%$ campuran di dapat nilai $8,0 \%$, dan pada $15 \%$ campuran di dapat $6,33 \%$. Pada pengujian CBR tidak terendam tanah asli didapat nilai 6,0\% sedangkan setelah dicampur $5 \%$ abu sabut kelapa didapat nilai $23,33 \%$, pada $10 \%$ campuran di dapat nilai $14,73 \%$, dan pada $15 \%$ campuran di dapat nilai $7,2 \%$. Maka dari itu dapat dipakai campuran $5 \%$ abu sabut kelapa karena dapat meningkatkan nilai CBR.
\end{abstract}

Kata kunci : abu sabut kelapa, CBR terendam dan CBR tak terendam

\section{Pendahuluan}

Tanah merupakan material kontruksi yang paling tua dan juga sebagai marerial dasar yang sangat penting karena merupakan tempat dimana stuktur bangunan didirikan dalam bidang pekerjaan konstruksi. Salah satu tanah yang tergolong jenis tanah yang tidak memenuhi syarat yaitu tanah yang terdapat di desa Cot Girek Kandang Kec. Muara Dua. Tanah tersebut merupakan yang sering mengalami kelongsoran, yang memiki ketinggian 10 meter dari tanah dasar, sehingga tidak memungkinkan untuk membangun struktur di atasnya. Tanah tersebut termasuk jenis tanah lempung yang memiliki daya dukung tanah yang rendah pada kondisi air yang tinggi, sifat menyusut bila kering dan mengembang bila basah.

Penelitian ini bertujuan untuk mengetahui seberapa besar pengaruh dari aditif tersebut menstabilisasi tanah lempung terhadap CBR terendam (soaked) dan CBR tak terendam (unsoaked). Pada penelitian ini tanah lempung akan diuji pemadatan tanah dengan campuran abu sabut kelapa.

\section{Tinjauan Kepustakaan}

\subsection{California Bearing Ratio (CBR)}

California Bearing Ratio (CBR) adalah suatu cara untuk menilai kekuatan tanah dasar. Kekuatan tanah dasar banyak tergantung kepada kadar airnya. Makin tinggi kadar airnya maka semakin kecil kekuatan nilai CBR dari tanah tersebut (Wesley, 1977). 
Alat percobaan yang di gunakan untuk menentukan besarnya CBR adalah alat penetrasi CBR, arloji pembacaan beban, mesin penetrasi, palu penumbuk, perlengkapan lainnya seperti CBR asli. Penentuan CBR berdasarkan persamaan:

$$
\begin{aligned}
& C B R_{01 "}=\frac{X}{3 \times 1000} \times 100 \\
& C B R_{02 "}=\frac{X}{3 \times 1500} \times 100
\end{aligned}
$$

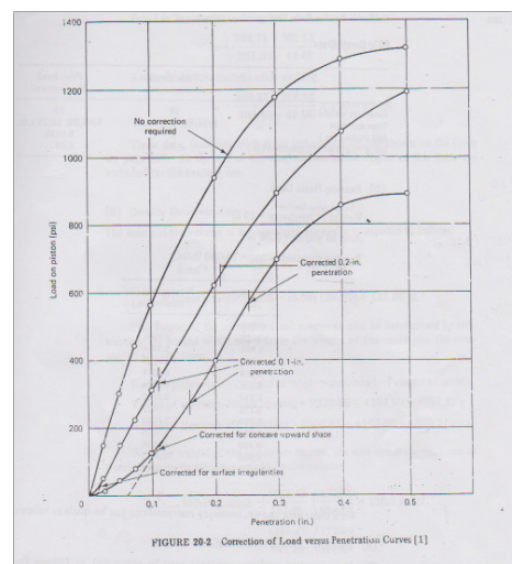

Gambar 1 Kurva penetrasi

\subsection{Material Pada Pengujian}

a. Tanah Lempung

Menurut Terzaghi (1987), lempung merupakan agregat partikel-partikel berukuran mikroskopik dan submikroskopik yang berasal dari pembusukan kimiawi unsur-unsur penyusun batuan, dan bersifat plastis dalam selang kadar air sedang sampai luas. Dalam keadaan kering sangat keras, dan tak mudah terkelupas hanya dengan jari tangan. Pada kadar air yang lebih tinggi (basah) lempung tersebut bersifat lengket.

\section{b. Abu Sabut Kelapa}

Pada pengujian Alexander (2003) telah melakukan pengujian mengenai abu sabut kelapa (ask) dan memperoleh komposisi senyawa ask (dalam satuan persen berat) yang terdiri dari $\mathrm{SiO} 2$ sebanyak 42,98\%, Al 2,26\%, dan $\mathrm{Fe}$ $1,16 \%$. Limbah abu sabut kelapa mengandung mineral yang terdiri dari silika, alumina dan oksida besi. Pengelolahan abu sabut kelapa sangat mudah, cukup dibakar dengan panas tertentu hingga membentuk abu-abu lalu saring hingga mendapatkan abu yang benar-benar halus.

\section{Metode Penelitian}

Penelitian ini merupakan pengaruh campuran abu sabu sabut kelapa pada tanah lempung terhadap nilai CBR terendam dan CBR tak terendam. Tujuan dari penelitian ini adalah untuk mengetahui seberapa besar pengaruh dari aditif tersebut menstabilisasi tanah lempung terhadap CBR terendam (soaked) dan CBR tak terendam (unsoaked), dan pengaruh campuran abu sabut kelapa pada tanah 
lempung terhadap nilai CBR dan dapat mengikat partikel- partikel tanah karena adanya kandungan silika pada abu sabut kelapa.

Tanah lempung berasal dari desa Cot Girek Kandang Kec. Muara Dua Aceh Utara dan Abu sabut kelapa yang terdapat di simpang keuramat dengan lolos saringan No. 200.

Tabel 1 Jumlah Benda Uji Untuk CBR

\begin{tabular}{|c|c|c|}
\hline Waktu (hari) & Persentase & Jumlah Benda Uji \\
\hline 0 & \multirow{2}{*}{$0 \%$ (tanah lempung $100 \%$ ) } & 3 buah \\
\hline 4 & & 3 buah \\
\hline 0 & \multirow{2}{*}{$5 \%+$ abu sabut kelapa } & 3 buah \\
\hline 4 & & 3 buah \\
\hline 0 & \multirow{2}{*}{$10 \%+$ abu sabut kelapa } & 3 buah \\
\hline 4 & & 3 buah \\
\hline 0 & \multirow{2}{*}{$15 \%+$ abu sabut kelapa } & 3 buah \\
\hline 4 & & 3 buah \\
\hline \multicolumn{2}{|c|}{ Jumlah Benda Uji } & 24 buah \\
\hline
\end{tabular}

Pelaksanaan penelitian ini dilakukan di Laboratorium Teknik Sipil Universitas Malikussaleh-Lhokseumawe. Adapun pelaksanaan penelitian, diperlihatkan pada Gambar 2.

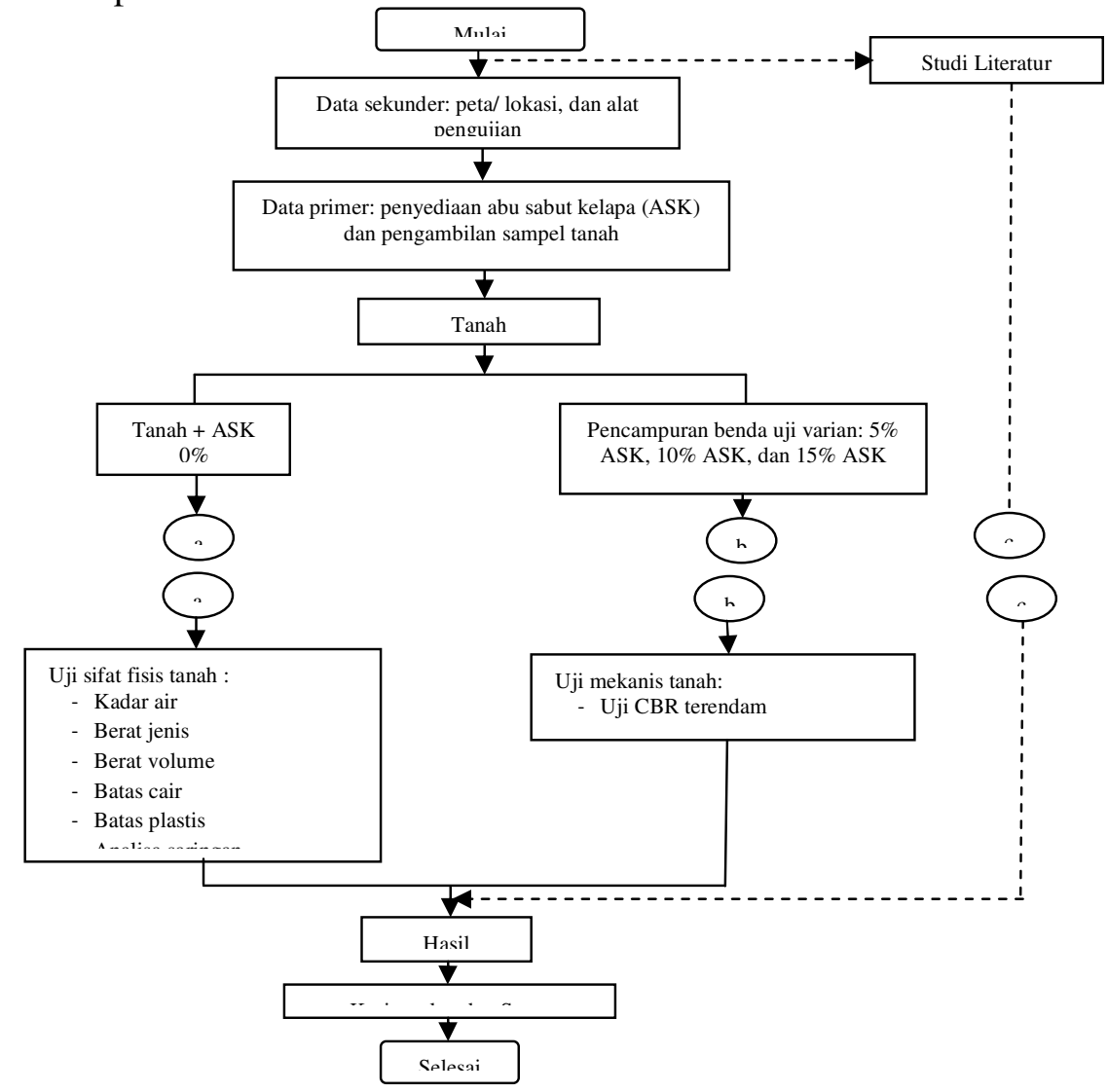

Gambar 2 Bagan Alir Penelitian

Pengaruh Campuran Abu Sabut Kelapa Dengan Tanah Lempung Terhadap Nilai CBR Terendam (Soaked) Dan CBR Tidak Terendam (Unsoaked) - Adzuha Desmi, Utari Sniwati 


\section{Hasil dan Pembahasan}

\subsection{Hasil}

\subsubsection{Pemeriksaan Sifat Fisis Tanah}

Hasil pengujian diperoleh kadar air rata-rata (W) sebesar 14,484 \%. Dengan jumlah kadar air yang demikian menggambarkan keadaan tanah tersebut memiliki kadar air yang tinggi. Pengujian berat jenis sebesar $2,653 \mathrm{gram} / \mathrm{cm}^{3}$, hal ini menggambarkan bahwa tanah tersebut dikatagorikan kepada tanah lempung organik karena nilai berat jenis tanah lempung organik berkisar antara 2,58-2,65 gram, (Braja M.Das 1985). Berdasarkan besaran berat volume berbeda disebabkan oleh ada butiran kasar yang berbeda banyak sehingga besar berat volume tanah basah rata-rata yaitu $1,829 \mathrm{gram} / \mathrm{cm}^{3}$ dan berat volume tanah kering sebesar 1,60 gram $/ \mathrm{cm}^{3}$. Pada pengujian atterberg limit terdiri dari Batas cair $(L L)$, batas plastis $(P L)$ dan indeks plastisitas $(P I)$, pengujian dilakukan pada tanah asli. Kurva batas cair yang dilakukan pada tanah asli diperlihatkan pada Gambar 3.

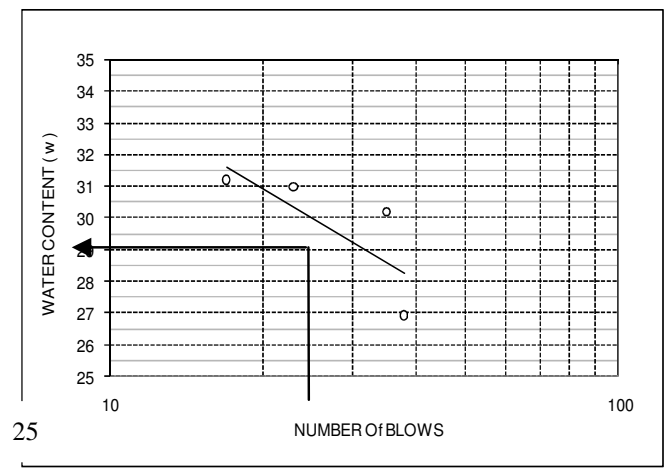

Gambar 3 grafik pengujian Liquid Limit

Pada gambar 31 di atas dapat dijelaskan bahwa nilai batas cair untuk tanah asli adalah $30 \%$. Selanjutnya dilakukan pengujian batas plastis diperoleh $24,8 \%$, dengan demikian nilai $P I$ dapat diperoleh dengan persamaan (2.5). PI sebesarLL $P L$, maka didapat nilai $P I$ adalah $5,2 \%$.

Setelah pengujian atterberg limit selesai maka selanjutnya dapat diketahui klasifikasi tanah dengan metode USCS karena lebih lazim digunakan pada mekanika tanah. Menentukan klasifikasi tanah berdasarkan Gambar 4.

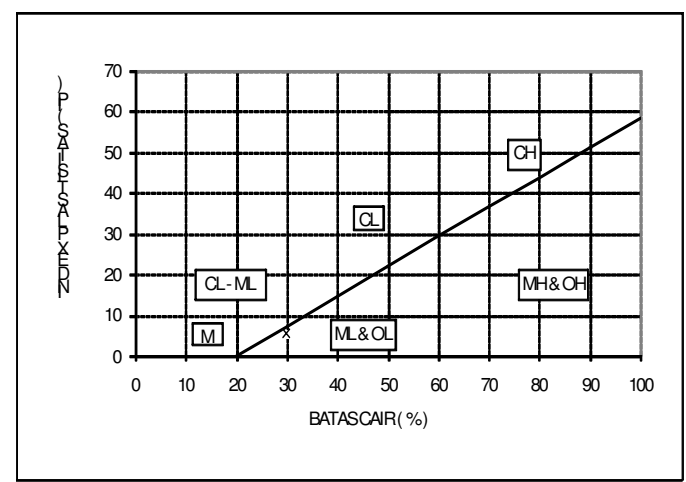

\section{Gambar 4 grafik klasifikasi tanah USCS}

Pengaruh Campuran Abu Sabut Kelapa Dengan Tanah Lempung Terhadap Nilai CBR Terendam (Soaked) Dan CBR Tidak Terendam (Unsoaked) - Adzuha Desmi, Utari Sniwati 
Menurut klasifikasi tanah USCS tanah tersebut termasuk ke dalam golongan ML dan OL yaitu lanau tak organik dan pasir sangat halus, serbuk batuan atau pasir halus berlanau dan berlempung dengan plastisitas rendah.

Hasil pengujian tanah tersebut mempunyai gradasi yang tidak baik, karena persentase lolos saringan tidak terkonsentrasi pada satu saringan.

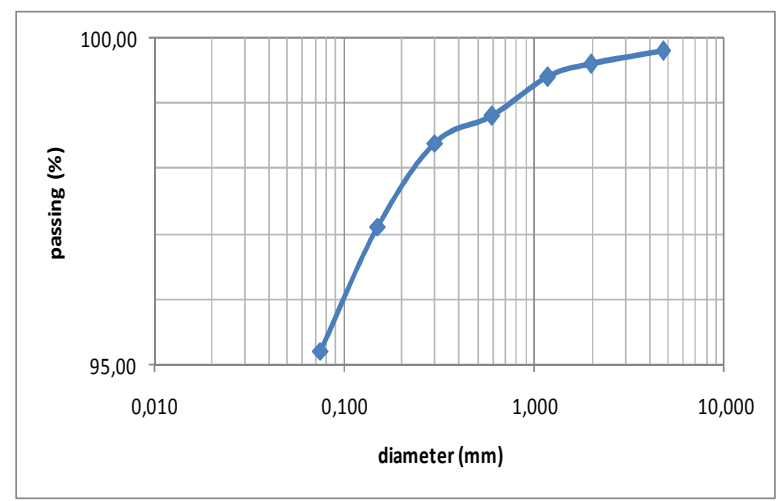

Gambar 5 grafik pengujian analisa saringan

Pada gambar 5 diatas dapat dijelaskan bahwa nilai yang didapatkan untuk lolos saringan No.200 adalah 95,20 \% menurut USCS termasuk kedalam golongan SC yaitu pasir berlanau, campuran pasir lempung.

Hasil pengujian analisa hidrometer didapat bahwa sampel tanah tersebut sesuai untuk $10 \%$ yang lebih halus (lolos ayakan) atau $\mathrm{D}_{10}$ dan diameter yang sesuai dengan $30 \%$ dan $60 \%$ lolos ayakan yang ditentukan dari grian size curce $\left(D_{30}, D_{60}\right)$. Dari harga-harga $D_{10}, D_{30}, D_{60}$ tersebut dapat diperoleh koefisien keseragaman $\left(\mathrm{C}_{\mathrm{u}}\right)$ serta koefisien gradasi $\left(\mathrm{C}_{\mathrm{c}}\right)$ dari ketiga sample tanah tersebut dapat diketahui koefisien bentuk lengkungan dan pembagian butiran adalah tanah bergradasi buruk.

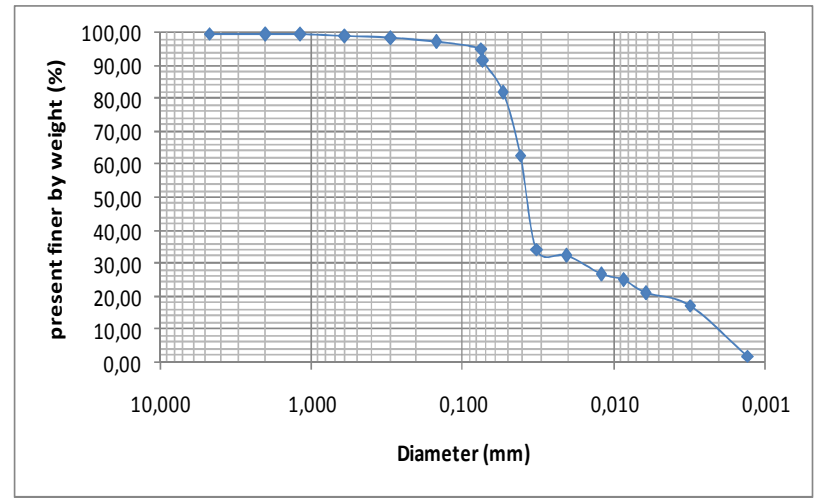

Gambar 6 Grafik pengujian analisa hidrometer

Pengaruh Campuran Abu Sabut Kelapa Dengan Tanah Lempung Terhadap Nilai CBR Terendam (Soaked) Dan CBR Tidak Terendam (Unsoaked) - Adzuha Desmi, Utari Sniwati 
Pengujian analisa hydrometer menghasilkan nilai $\mathrm{D}_{10}$ sebesar 0,$15 ; \mathrm{D}_{30}$ sebesar 0,2; $\mathrm{D}_{60}$ sebesar 0,3 maka nilai $\mathrm{C}_{\mathrm{u}}$ adalah 2 dan $\mathrm{C}_{\mathrm{c}}$ adalah 0,002. Dari hasil $\mathrm{C}_{\mathrm{u}}$ dan $\mathrm{C}_{\mathrm{c}}$ maka tanah tersebut termasuk kedalam tanah bergradasi buruk.

Pengujian proctor test dilakukan menggunakan tanah asli yang dipadatkan pada keadaan kadar air optimum sehingga tercapai keadaan paling padat.

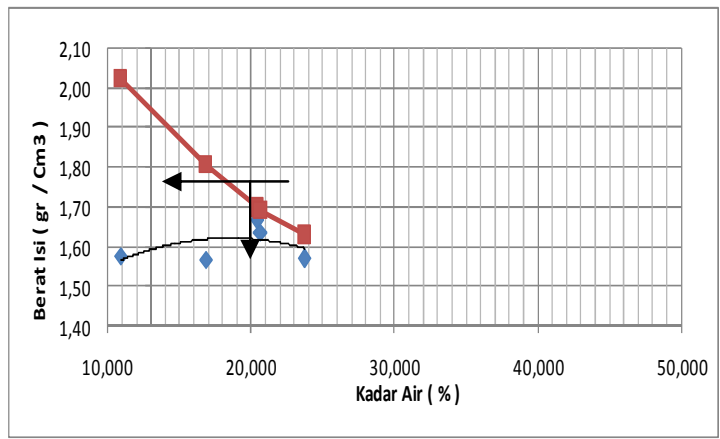

Gambar 7 Grafik pemadatan tanah

Pada kurva Gambar 4, diperoleh nilai kadar air optimum $\left(W_{\text {opt }}\right)$ dan berat isi kering $\left(\gamma_{d}\right)$ sebesar : tanah asli yang didapatkan ( $W_{\text {opt }}$ sebesar $18,528 \%$, dan $\gamma_{d}$ sebesar $1,60 \mathrm{gr} / \mathrm{cm}^{3}$ ). Dengan melakukan pengujian yang dipadatkan hasil akhir dari nilai pemadatannya yang bila grafik dihubungkan dengan grafik pengujian CBR maka akan didapat CBR rencana yang dikehendaki dimana kadar air CBR diambil berdasarkan kadar air optimum pada pengujian pemadatan.

\subsubsection{Pemeriksaan Sifat Mekanis Tanah}

Pengujian CBR terendam menunjukkan bahwa nilai CBR yang di hasilkan pada pengujian CBR terendam untuk $10 \mathrm{x}$ tumbukan di dapat nilai CBR pada tanah asli sebesar 3,69\%, pada campuran 5\% abu sabut kelapa didapat nilai CBR sebesar 6,17\%, pada variasi campuran $10 \%$ didapat nilai CBR sebesar 5,33\%, dan pada variasi campuran $15 \%$ didapat nilai CBR sebesar 5,0\%. Pada tumbukan $25 \mathrm{x}$ di dapat nilai CBR pada tanah asli sebesar 5\%, pada campuran 5\% abu sabut kelapa didapat nilai CBR sebesar $16,67 \%$, pada campuran $10 \%$ abu sabut kelapa di dapat nilai CBR sebesar 8,0\%, dan pada campuran $15 \%$ abu sabut kelapa di dapat nilai CBR sebesar 6,33\%.

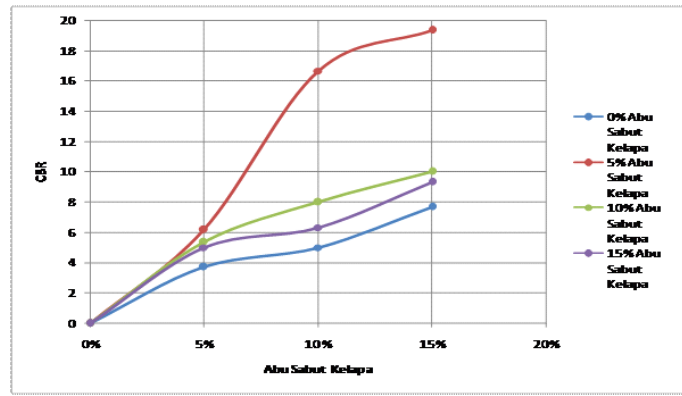

\section{Gambar 8 Grafik gabungan CBR terendam dengan Abu Sabut Kelapa}

Pengaruh Campuran Abu Sabut Kelapa Dengan Tanah Lempung Terhadap Nilai CBR Terendam (Soaked) Dan CBR Tidak Terendam (Unsoaked) - Adzuha Desmi, Utari Sniwati 
Pada tumbukan $56 \mathrm{x}$ di dapat nilai CBR pada tanah asli sebesar 7,67\%, pada campuran 5\% abu sabut kelapa di dapat nilai CBR sebesar 19,33\%, pada campuran $10 \%$ abu sabut kelapa di dapat nilai CBR sebesar $10 \%$, dan pada campuran $15 \%$ abu sabut kelapa di dapat nilai CBR sebesar 9,33\%. Pada penelitian ini penambahan abu sabut kelapa dengan kadar air optimum (Wopt) pada campuran 5\% nilai CBR semakin meningkat dibandingkan dengan campuran $10 \%$ dan $15 \%$ abu sabut kelapa, dan pada campuran $10 \%$ dan $15 \%$ nilai CBR semakin meningkat dibandingkan dengan tanah asli.

Pengujian CBR tak terendam menunjukkan bahwa nilai CBR yang di hasilkan pada pengujian CBR tidak terendam untuk $10 \mathrm{x}$ tumbukan di dapat nilai CBR tanah asli sebesar 5\%, pada campuran 5\% abu sabut kelapa di dapat nilai CBR sebesar $12 \%$, pada campuran $10 \%$ abu sabut kelapa di dapat nilai CBR sebesar 9,33\%, dan pada campuran $15 \%$ abu sabut kelapa di dapat nilai CBR sebesar 6,0\%. Untuk tumbukan $25 \mathrm{x}$ pada tanah asli di dapat nilai CBR sebesar $6 \%$, pada campuran 5\% abu sabut kelapa di dapat nilai CBR sebesar 23,33\%, pada campuran $10 \%$ abu sabut kelapa di dapat nilai CBR sebesar 14,73\%, dan pada campuran $15 \%$ abu sabut kelapa di dapat nilai $7,2 \%$. Pada $56 \mathrm{X}$ tumbukan di dapat nilai CBR pada tanah asli sebesar 6,8\%, pada campuran 5\% abu sabut kelapa di dapat nilai CBR sebesar 832,67\%,pada campuran $10 \%$ abu sabut kelapa di dapat nilai CBR sebesar 28,13\% dan pada campuran $15 \%$ abu sabut kelapa di dapat nilai CBR sebesar $8,0 \%$. Pada penelitian ini penambahan abu sabut kelapa dengan kadar air optimum (Wopt) pada campuran 5\% nilai CBR semakin meningkat dibandingkan dengan campuran $10 \%$ dan $15 \%$ abu sabut kelapa, dan pada campuran $10 \%$ dan $15 \%$ nilai CBR semakin meningkat dibandingkan dengan tanah asli.

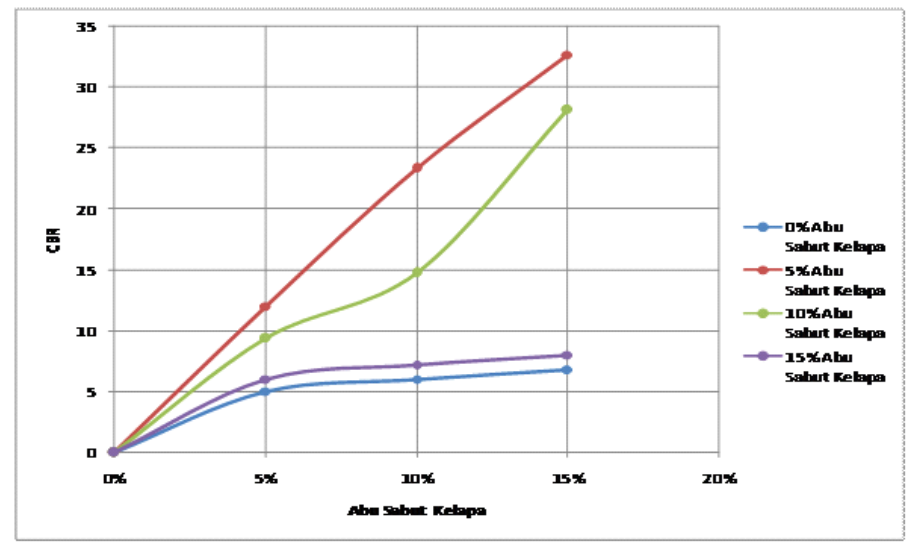

\section{Gambar 9 Grafik gabungan CBR tidak terendan dengan Abu Sabut Kelapa}

Pengujian swelling pada CBR terendam seperti padaTabel 2 dapat diperlihatkan bahwa pada tumbukan 56 x nilai dan pada campuran $15 \%$ swelling semakin rendah berarti tanah tersebut sanggup menahan beban yang diberikan yaitu sebesar $10 \mathrm{lbs}$ atau 4,5 kg selama 96 jam atau 4 hari perendaman, maka di dapat hasil 0 , atau tidak terjadi penurunan pada saat perendaman.

Pengaruh Campuran Abu Sabut Kelapa Dengan Tanah Lempung Terhadap Nilai CBR Terendam (Soaked) Dan CBR Tidak Terendam (Unsoaked) - Adzuha Desmi, Utari Sniwati 
Tabel 2 Pengujian swelling

\begin{tabular}{|c|r|r|r|r|}
\hline Tumbukan & \multicolumn{1}{|c|}{$0 \%$} & \multicolumn{1}{c|}{$5 \%$} & \multicolumn{1}{c|}{$10 \%$} & \multicolumn{1}{c|}{$15 \%$} \\
\hline $10 \mathrm{X}$ & 0,38 & 0,19 & 0,09 & 0,01 \\
\hline $25 \mathrm{X}$ & 0,0034 & 0,09 & 0,18 & 0,00083 \\
\hline $56 \mathrm{X}$ & 0,0017 & 0,05 & 0,09 & 0 \\
\hline
\end{tabular}

\subsection{Pembahasan}

Tanah lempung bersifat sangat kohesif, kenaikan air tinggi sehingga perlu campuran abu sabut kelapa sebagai bahan stabilisasinya. Sampel tanah lempung diambil dari desa Cot Girek Kandang Kecamatan Muara Dua, sedangkan sampel abu sabut kelapa di dapat didesa Keude Simpang Empat Kecamatan Simpang Keuramat. Komposisi campuran abu sabut kelapa sebanyak 5\%, 10\% dan 15\%.

Dari kurva percobaan menggambarkan bahwa pengaruh campuran variasi abu sabut kelapa pada tanah asli dengan penambahan campuran kadar air optimum (Wopt), menunjukkan bahwa nilai beban semakin meningkat setelah dilakukan penambahan persentase $5 \%$ abu sabut kelapa, sedangkan pada penambahan persentase $10 \%$ dan $15 \%$ nilai beban semakin menurun dibandingkan dengan campuran persentase 5\%, tetapi penambahan persentase $10 \%$ dan $15 \%$ semakin meningkat dibandingkan nilai beban pada tanah asli, hal ini disebabkan karena adanya campuran abu sabut kelapa sebanyak 5\%, semakin berkurangnya kadar air dimana sifat abu sabut kelapa memiliki daya resap air lebih tinggi dari pada tanah. Hasil pengujian CBR, maka dapat dipakai untuk penimbunan pada campuran 5\% abu sabut kelapa. Ini menunjukkan bahwa penambahan bahan campuran abu sabut kelapa mampu meningkatkan daya dukung tanah lempung dan tanah tersebut akan menjadi lebih kokoh.

Pada pengujian ini dilakukan dua metode yaitu pengujian CBR terendam dan pengujian CBR tidak terendam, dilakukan karena kondisi tanah terkadang banyak air pada musim hujan dan sedikit air pada musim kemarau. Pada pengujian CBR terendam dilakukan perendaman selama 96 jam (4 hari) rendaman. Pada pengujian swelling untuk pengujian CBR terendam didapat nilai pada campuran $15 \%$ abu sabut kelapa dan pada tumbukan $56 \mathrm{x}$ di dapat nilai swelling semakin kecil yaitu sekin bagus untuk keadaan rendaman karena sanggup menahan beban sebesar $10 \mathrm{lbs}$ atau 4,5 kg. Hal ini menunjukkan bahwa dengan penambahan sebanyak 5\% abu sabut kelapa dapat meningkatkan nilai CBR pada tanah lempung. Dari pengujian kedua menggambarkan bahwa nilai CBR tak terendam lebih tinggi dibandingkan nilai CBR terendam, sedangkan pada pengujian swelling penambahan $15 \%$ abu sabut kelapa dan pada $56 \mathrm{x}$ tumbukan yang dapat menahan beban sebesar 4,5 $\mathrm{kg}$ atau $10 \mathrm{lbs}$ pada perendaman selama 96 jam.

Dengan melakukan percobaan ini maka didapat nilai CBR rencana yang dikehendaki di mana kadar air CBR diambil berdasarkan kadar air optimum pada tes kepadatan. Dengan didapat nilai CBR maka kita dapat menentukan tanah tersebut bisa dipakai ataupun tidak, misalnya timbunan badan jalan atau gedung.

Pengaruh Campuran Abu Sabut Kelapa Dengan Tanah Lempung Terhadap Nilai CBR Terendam (Soaked) Dan CBR Tidak Terendam (Unsoaked) - Adzuha Desmi, Utari Sniwati 
Hasil pengujian sifat mekanis tanah asli yang meliputi kadar air optimum, kepadatan kering maksimum dan CBR maka dapat dikatakan tanah mempunyai daya dukung CBR rendah, yaitu 4,5\% untuk CBR terendam sedangkan untuk CBR tidak terendam didapat nilai CBR yaitu $5,5 \%$.

\section{Kesimpulan dan Saran}

\subsection{Kesimpulan}

Dari hasil penelitian dan pembahasan dapat diambil beberapa kesimpulan sebagai berikut:

1. Untuk pengujian sifat-sifat fisis berdasarkan klasifikasi USCS tanah dapat di golongkan pada jenis tanah lanau dan lempung berlanau karena mengandung pasir yang sangat halus.

2. Pada pengujian sifat mekanis tanah dilakukan pengujian CBR terendam, pada campuran $0 \%$ didapat nilai CBR sebesar 5,0\%, pada campuran 5\% didapat nilai CBR sebesar $16,67 \%$, pada campuran $10 \%$ didapat nilai CBR sebesar $8,0 \%$, dan pada campuran $15 \%$ didapat nilai CBR sebesar 6,33\%. Maka dapat disimpulkan bahwa tanah dapat dipakai untuk meningkatkan nilai CBR dengan mencampurkan abu sabut kelapa sebanyak 5\%.

3. Pengujian CBR tidak terendam diperoleh nilai CBR tanah asli atau $0 \%$ didapat CBR sebesar $6,0 \%$, pada campuran $5 \%$ didapat CBR sebesar 23,33\%, pada campuran $10 \%$ didapat CBR sebesar $14,73 \%$, dan pada campuran $15 \%$ didapat CBR sebesar 7,2\%. Maka dapat disimpulkan bahwa yang dapat meningkatkan nilai CBR tanah adalah pada campuran $5 \%$ abu sabut kelapa.

\subsection{Saran}

Dari kesimpulan yang dipaparkan diatas, terdapat beberapa saran yang diusulkan, diantaranya adalah:

1. Untuk peneliti yang ingin melanjutkan penelitian tentang campuran abu sabut kelapa dapat melakukan penelitian dengan variasi abu sabut kelapa dibawah $5 \%$ dan berbeda variasi.

2. Disarankan kepada para peminat bidang tanah untuk melanjutkan penelitian dengan bahan stabilisasi lainnya.

\section{Daftar Kepustakaan}

Anonim, ASTM (American Society For Testing And Materials) D698. Standard test method D.

Bowles, J.E., 1993, Sifat-Sifat Fisis Dan Geoteknis Tanah (Mekanika Tanah). Terjemahan Johan Kelana Hainim, Erlangga Jakarta.

Craig, R.F., 1994, Mekanika tanah. Edisi ke-empat. Erlangga Jakarta.

Das, Braja M., 1988, Mekanika Tanah, Jilid 1. Erlangga Jakarta.

Das, Braja M., 1985, Mekanika Tanah, Jilid 2. Erlangga Jakarta.

Hardiyatmo, H. C, 2002. Mekanika Tanah I, PT. Gramedia Pustaka Utama, Jakarta.

Pengaruh Campuran Abu Sabut Kelapa Dengan Tanah Lempung Terhadap Nilai CBR Terendam (Soaked) Dan CBR Tidak Terendam (Unsoaked) - Adzuha Desmi, Utari Sniwati 
Jufrizal., 2012, Pengaruh Stabilisasi Tanah Ekspansif Dengan Serbuk Kayu Dan Kapur Terhadap Nilai CBR, Jurusan Teknik Sipil, Unimal, Lhokseumawe.

Terzaghi, K, Ralph B. Peck, 1987, Mekanika Tanah Dalam Praktek Rekayasa. Erlangga Jakarta.

Verhoef, P.n.w., 1994, Geologi Untuk Teknik Sipil, Erlangga Jakarta.

Wesley, L.d., 1977, Mekanika Tanah, Pekerjaan Umum Jakarta

Seta, W, 2015, Perilaku tanah ekspansif yang dicampur dengan pasir untuk subgrade, Tesis, Universitas diponegoro 